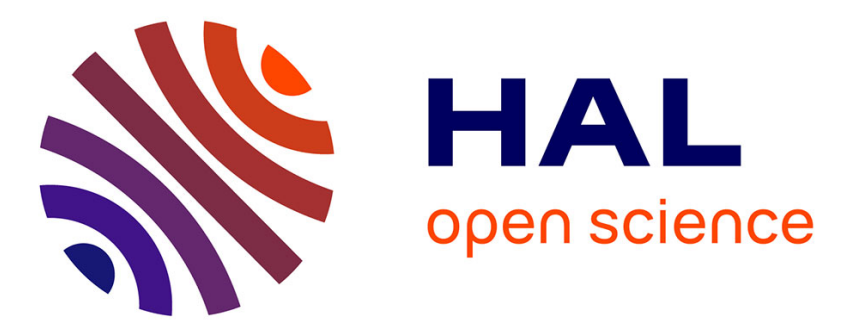

\title{
Complementary Synthetic Approaches to Elongated Polycyclic Arenes with Regioisomeric Carboxylic Substitution Patterns
}

\author{
Harald Bock, Pauline Carré, Elisabeth A. Hillard, Fabien Durola
}

\section{- To cite this version:}

Harald Bock, Pauline Carré, Elisabeth A. Hillard, Fabien Durola. Complementary Synthetic Approaches to Elongated Polycyclic Arenes with Regioisomeric Carboxylic Substitution Patterns. European Journal of Organic Chemistry, 2014, 76 (15), pp. 1028-1032. 10.1002/ejoc.201403339 . hal01117719

\author{
HAL Id: hal-01117719 \\ https://hal.science/hal-01117719
}

Submitted on 11 Oct 2017

HAL is a multi-disciplinary open access archive for the deposit and dissemination of scientific research documents, whether they are published or not. The documents may come from teaching and research institutions in France or abroad, or from public or private research centers.
L'archive ouverte pluridisciplinaire $\mathbf{H A L}$, est destinée au dépôt et à la diffusion de documents scientifiques de niveau recherche, publiés ou non, émanant des établissements d'enseignement et de recherche français ou étrangers, des laboratoires publics ou privés. 


\title{
Complementary Synthetic Approaches to Elongated Polycyclic Arenes with Regioisomeric Carboxylic Substitution Patterns
}

\author{
Harald Bock, ${ }^{*[a]}$ Pauline Carré, ${ }^{[b]}$ Elizabeth A. Hillard, ${ }^{[a]}$ and Fabien Durola*[a]
}

Keywords: Arenes / Polycycles / Cyclization / Donor-acceptor systems / Chromophores

The reaction of 1,5-dibromoanthracene with butyllithium and diethyloxalate followed by saponification gives anthrylene-1,5-diglyoxylic acid as a bifunctional reactant. Its double condensation with 2-bromophenylacetic acid, followed by double cyclization, leads to a bright-orange nearlinear dinaphtho-anthracene-tetracarboxdiimide with substituents on the naphthalene moieties. An analogous condensation-cyclization sequence of 2,5-dibromophenylene-1,4diacetic acid with 1-naphthylglyoxylic acid leads to an iso- meric red diimide substituted on the anthracene nucleus. The striking difference in band gaps shows that diimide substitution on the central moiety of diareno[ $a, h]$ anthracenes is particularly efficient in inducing long-wavelength absorption. The substitution dependence of the band gap is found to be mainly caused by a variation of the reduction potentials with substituent position, whereas the oxidation potentials are largely substitution-independent.

\section{Introduction}

Carboxy-substituted polycyclic aromatic chromophores are attractive both as rather stable dyes and as charge-transport materials in organic electronics, ${ }^{[1]}$ and their optical and electronic properties have been reported to vary significantly between closely related species such as between planar and helical regioisomers. ${ }^{[2]}$ Since the advent of novel polymeric forms of $\mathrm{sp}^{2}$-hybridized carbon such as singlewalled carbon nanotubes ${ }^{[3]}$ and single-sheet graphene, ${ }^{[4]}$ they are also of interest as model systems for polymeric graphene nanoribbons ${ }^{[5]}$ with defined edge geometry and solubilizing and electronically modulating lateral substituents.

We have recently shown ${ }^{[6]}$ that the glyoxylic Perkin reaction $^{[7]}$ followed by palladium-catalyzed dehydrobromina$\operatorname{tion}^{[8]}$ is an efficient tool with which to construct carboxyfunctionalized polycyclic arenes, and that 2,5-dibromophenylene-1,4-diacetic acid $\mathbf{1}$ is an appropriate and easily accessible bifunctional synthon that can be used to build up tetracarboxy-substituted diareno $[a, h]$ anthracenes in combination with two molecules of an arylglyoxylic acid.

The derived diimides $\mathbf{2}$ and $\mathbf{3}$, obtained through the reaction of 1 with pyrenyl-1-glyoxylic acid or perylenyl-3-glyox-

[a] Centre National de la Recherche Scientifique, Centre de Recherche Paul Pascal,

115 avenue Schweitzer, 33600 Pessac, France www.crpp-bordeaux.cnrs.fr

[b] Université de Bordeaux, Centre de Recherche Paul Pascal, 115 avenue Schweitzer, 33600 Pessac, France

E-mail: bock@crpp-bordeaux.cnrs.fr ylic acid, showed exceptionally large bathochromic shifts of more than $100 \mathrm{~nm}$ of the longest-wavelength absorption maximum compared with the corresponding tetraesters $\mathbf{4}$ and 5 (Figure 1). Diimide substitution in the 3,4- and 7,8positions of the central anthracene unit of diareno[ $[a, h]$ anthracenes thus appears to be a particularly efficient means to impart long-wavelength absorption and small electronic band gaps to such polycyclic aromatic chromophores.
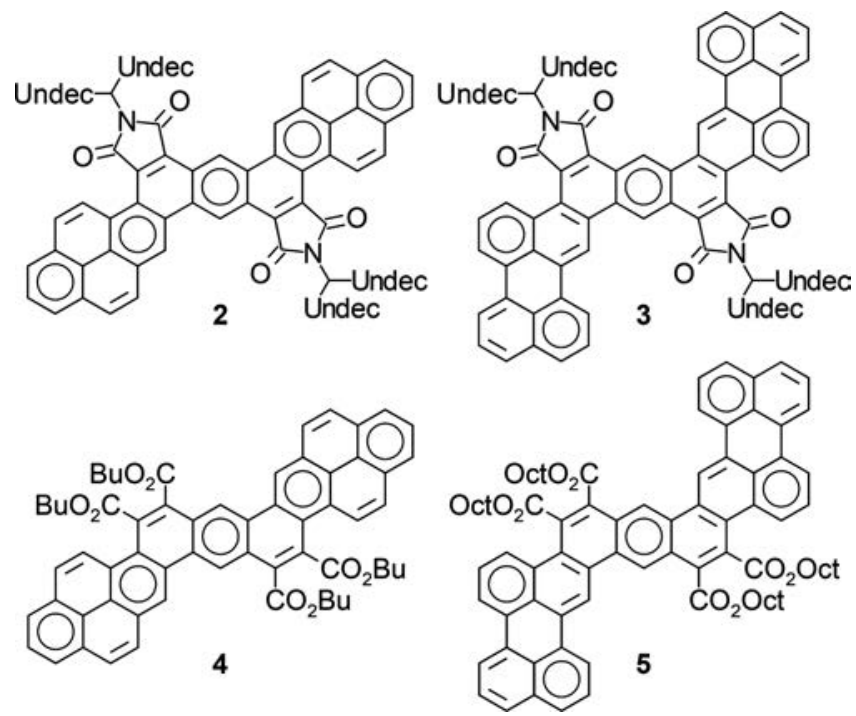

Figure 1. Diareno[ $a, h]$ anthracene-diimides 2 (crystal color: purple) and 3 (green) that exhibit very strong bathochromic absorption band shifts compared with the corresponding tetraesters 4 (orange) and 5 (red). ${ }^{[6]}$ Undec $=n$-undecyl, Oct $=n$-octyl.

Tetracarboxy-substituted elongated arenes should also be accessible by the inverse Perkin approach; that is, 
through the condensation of a central arylene-diglyoxylic acid as a bifunctional synthon with two peripheral $o$-bromoarylacetic acid molecules.

If anthrylene-1,5-diglyoxylic acid $\mathbf{6}$ is chosen as central building block, diareno $[a, h]$ anthracenes similar to those obtained from 1 should be accessible, but with the carboxylic substituents in less central positions.

\section{Results and Discussion}

Whereas the synthesis of $\mathbf{6}$ by Friedel-Crafts-type approaches is not easily envisaged, 1,5-dibromoanthracene 7 is readily available from 1,5-diaminoanthraquinone through reaction with $\mathrm{CuBr}_{2}$ followed by reduction. ${ }^{[9]} \mathrm{We}$ found that the reaction of dibromoarene 7 with butyllithium at low temperature followed by addition of excess diethyl oxalate yields diglyoxylic ester $\mathbf{8}$ in $80 \%$ yield, which gives $\mathbf{6}$ upon basic hydrolysis (Figure 2). In principle, this approach, which is based on oxalate quenching of a dilithiated arenedianion, should be applicable to a variety of polycyclic dibromoarenes to yield the corresponding diglyoxylic acids.

The simplest $o$-bromoarylacetic acid is commercially available 2-bromophenylacetic acid 9, which should condense with $\mathbf{6}$ to give bismaleate $\mathbf{1 0}$ after esterification, to give the seven-ring all-kata-annellated tetraester $\mathbf{1 1}$ and diimide 12 after palladium-mediated double dehydrobromination.

The feasibility of the path from $\mathbf{6}$ to $\mathbf{1 1}$ and $\mathbf{1 2}$ can be compared with the construction of analogous targets from 1. To build up the same polycyclic system as in $\mathbf{1 1}$ and $\mathbf{1 2}$ but with carboxylic substituents in the more central positions that led to very long-wavelength absorption in $\mathbf{2}$ and 3, 1 has to be condensed with naphthyl-1-glyoxylic acid $\mathbf{1 3}^{[10]}$ to give bismaleate $\mathbf{1 4}$, which yields doubly cyclized tetraester $\mathbf{1 5}$ and diimide $\mathbf{1 6}$ after dehydrobromination.

The Perkin condensation of diglyoxylic acid $\mathbf{6}$ with monoacetic acid 9 (2.4 equiv.) in tetrahydrofuran (THF) heated to reflux over $24 \mathrm{~h}$ followed by esterification in situ, gave a significantly lower yield of bismaleate $10(32 \%)$ than the complementary Perkin condensation of diacetic acid $\mathbf{1}$ with monoglyoxylic acid $\mathbf{1 3}$ (2.4 equiv.) to bismaleate $\mathbf{1 4}$ $(53 \%)$, and traces of unreacted diglyoxylic acid could be recovered from the former reaction in the form of $\mathbf{8}$. Longer reaction times did not improve the yield of $\mathbf{1 0}$, and higher temperatures (reflux in dioxane) led to substantial darkening during the reaction. The modest yield of $32 \%$ appears reasonable if we consider that it is an overall yield of six individual reactions (two Perkin condensations and four esterifications) with an average yield of $83 \%\left(0.827^{6}=0.32\right)$. By analogy, the yield of $53 \%$ for $\mathbf{1 4}$ corresponds to an average yield of $90 \%\left(0.900^{6}=0.53\right)$ over six individual reactions.

The double intramolecular ring closure by palladiumcatalyzed dehydrobromination of $\mathbf{1 4}$ to $\mathbf{1 5}$ proceeds with notably higher yield $(69 \%)$ than the analogous reaction of 10 to $11(46 \%)$, even though the reaction sites in $\mathbf{1 4}$ are sterically less accessible to the catalyst than those in $\mathbf{1 0}$. We

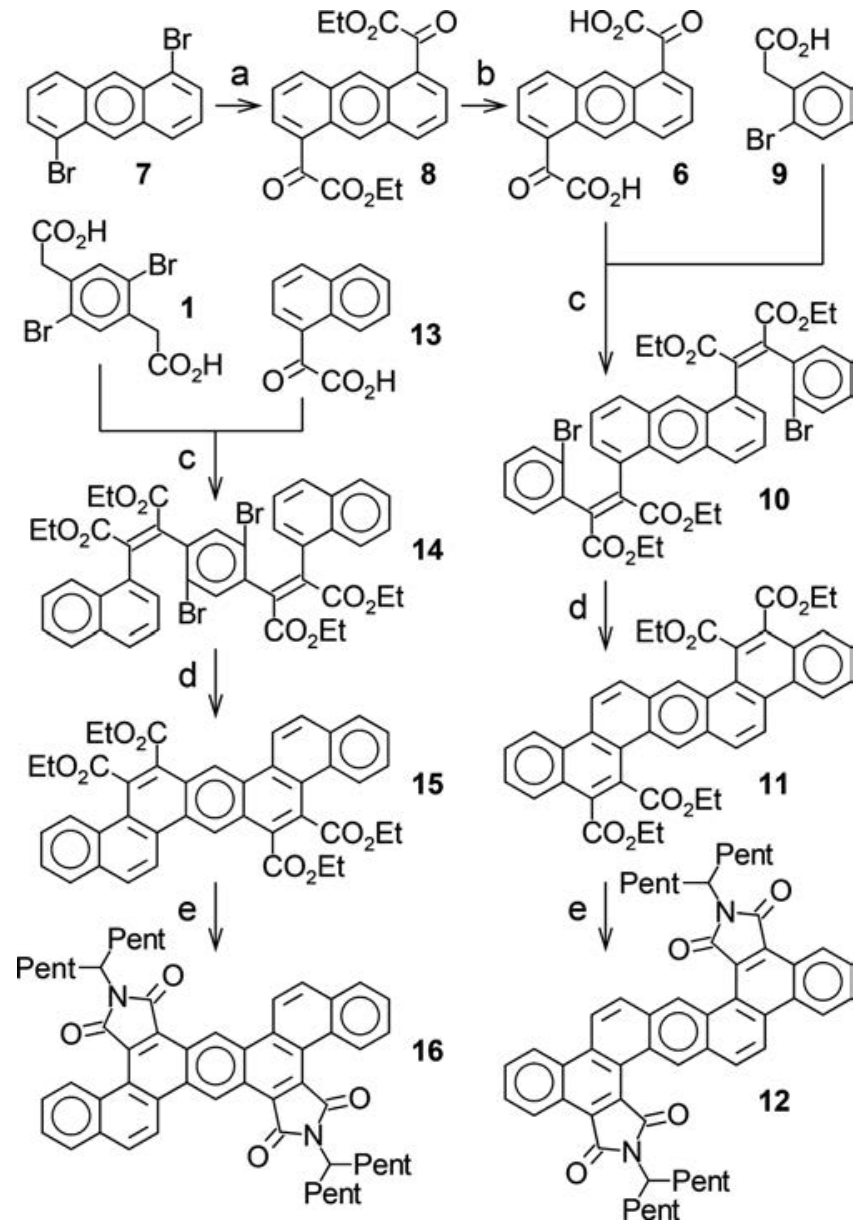

Figure 2. Synthesis of dinaphtho[1,2-a; $\left.1^{\prime}, 2^{\prime}-h\right]$ anthracenes with different carboxylic substitution patterns. Reagents and conditions: (a) THF, $-94{ }^{\circ} \mathrm{C}, \mathrm{BuLi}, 4 \mathrm{~h}$, then addition of $\mathrm{EtO}_{2} \mathrm{CCO}_{2} \mathrm{Et}, 1 \mathrm{~h}$, $80 \%$; (b) $\mathrm{NaHCO}_{3}, \mathrm{EtOH} / \mathrm{H}_{2} \mathrm{O}$, reflux, 4 h, $100 \%$; (c) $\mathrm{NEt}_{3}, \mathrm{Ac}_{2} \mathrm{O}$, THF, reflux, $20 \mathrm{~h}$, then addition of EtOH, EtBr, DBU, reflux, $24 \mathrm{~h}$, $32 \%(10)$ or $53 \%(14)$; (d) $\mathrm{Pd}(\mathrm{OAc})_{2}, \mathrm{PCy}_{3}, \mathrm{~K}_{2} \mathrm{CO}_{3}$, DMA, $110{ }^{\circ} \mathrm{C}$, $16 \mathrm{~h}, 46 \%$ (11) or $69 \%(15)$; (e) $\mathrm{Pent}_{2} \mathrm{CHNH}_{2}$, imidazole, o$\mathrm{C}_{6} \mathrm{H}_{4} \mathrm{Cl}_{2}$, reflux, $6 \mathrm{~h}, 75 \%$ (12) or $85 \%$ (16); Pent $=n$-pentyl.

suspect that in sterically less accessible $\mathbf{1 4}$, ring closure under palladium ejection is more favored than in $\mathbf{1 0}$ with respect to unwanted palladium-catalyzed isomerizations. ${ }^{[11]}$

The two diimides $\mathbf{1 2}$ and 16, which differ only in the positions of the imide substituents, are easily distinguished by their colors: Whereas the exo-isomer $\mathbf{1 2}$ is bright-orange in the solid state and yellow in dilute chloroform solution, the endo-isomer $\mathbf{1 6}$ is red in the solid state and deep-orange in dilute chloroform solution. This translates to absorption spectra ( $20 \mu \mathrm{M}$ in chloroform) with respective longest-wavelength absorption peaks at 490 (12) and $532 \mathrm{~nm}$ (16) (Figure 3$)$. The tetraesters show corresponding longest-wavelength peaks at $400(\mathbf{1 1})$ and $423(\mathbf{1 5}) \mathrm{nm}$, with resulting shifts of $90 \mathrm{~nm}$ from exo-ester 11 to exo-imide 12 and $109 \mathrm{~nm}$ from endo-ester $\mathbf{1 5}$ to endo-imide 16. This comparison between otherwise identical systems differing only in their carboxylic substitution positions establishes that the particularly bathochromic absorption of systems such as $\mathbf{2}$, $\mathbf{3}$, and $\mathbf{1 6}$ is caused in substantial part by the localization of 
the substituents in the 3,4- and 7,8-positions of the central anthracene moiety of these diareno[ $a, h]$ anthracenes. The respective absorption edges of 565 (16), 525 (12), 440 (15), and $425 \mathrm{~nm}$ (11) correspond to optical band gaps of 2.19, $2.36,2.82$, and $2.92 \mathrm{eV}$, respectively.

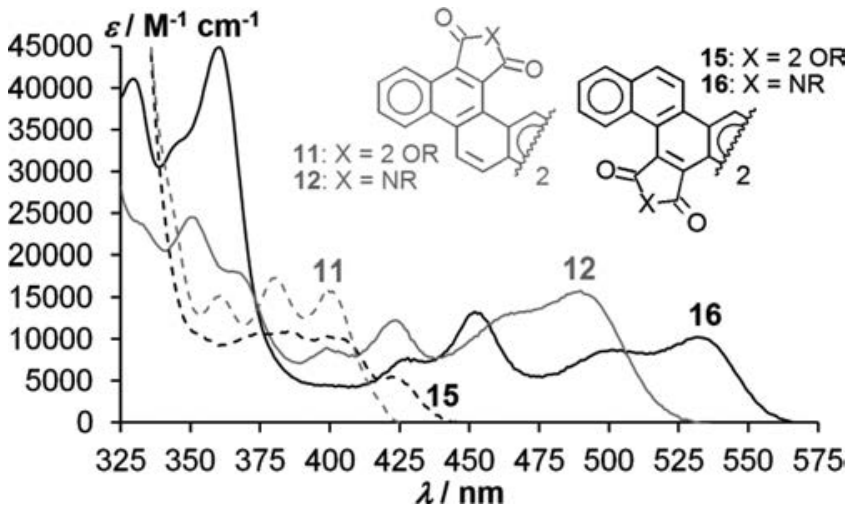

Figure 3. Absorption spectra of isomeric tetraesters $\mathbf{1 1}$ and $\mathbf{1 5}$ (dashed) and diimides 12 and $\mathbf{1 6}$ (continuous), $20 \mu \mathrm{M}$ in $\mathrm{CHCl}_{3}$. Gray curve: 11 and 12, black curve: 15 and $\mathbf{1 6 .}$

The anodic and cathodic electrochemistry of endo-ester 15, endo-imide 16, exo-ester 11, and exo-imide 12 were evaluated by cyclic voltammetry $(\mathrm{CV})$ and by differential pulse voltammetry (DPV) in dichloromethane between +1.7 and $-2.0 \mathrm{~V}$ vs. $\mathrm{Ag} / \mathrm{AgNO}_{3}$. Both endo compounds 15 and 16 showed a quasireversible to reversible oxidation at approximately $E_{1 / 2}=1.18 \mathrm{~V}$ vs. the ferrocenium/ferrocene couple. In the exo series, only imide 12 displayed reversible oxidation, at $E_{1 / 2}=1.02 \mathrm{~V}$, whereas an irreversible oxidation of ester 11 occurred at $E_{1 / 2}=1.04 \mathrm{~V}$. Overall, the oxidation behavior is thus only weakly dependent both on the nature of the substituents and on their location. The oxidations are therefore likely centered on the aromatic core.

Scanning cathodically, both endo compounds $\mathbf{1 5}$ and $\mathbf{1 6}$ displayed two reversible reduction processes. The endo-ester 15 was more difficult to reduce than the endo-imide 16, with first reduction potentials of $-1.85 \mathrm{~V}$ for 15 and $-1.35 \mathrm{~V}$ for 16, but the separation between the two reduction waves, $\Delta E_{1 / 2}$, was similar (230 mV for 15 and $260 \mathrm{mV}$ for 16). On the other hand, the first reduction potentials of the exo compounds ( $-2.03 \mathrm{~V}$ for 11 and $-1.60 \mathrm{~V}$ for 12) were significantly more negative than those for $\mathbf{1 5}$ and 16, and showed small peak separations of $120 \mathrm{mV}$ (ester 11) and $60 \mathrm{mV}$ (imide 12) and the two CV waves were essentially superposed.

The extent of coupling between redox centers in mixed valence species can be estimated by the stability of the mixed-valent state. This thermodynamic parameter can be evaluated by the comproportionation constant $K_{\mathrm{C}}=$ $\exp \left(\Delta E_{1 / 2} / 25.69\right),{ }^{[12]}$ which depends on the peak separation $\Delta E_{1 / 2}$ of the two reductions in this case. A $K_{\mathrm{C}}$ value of $10^{6}$ or above is generally accepted to imply strong electronic coupling and consequently full electron delocalization in the mixed valent state, corresponding to a Class III compound in the Robin and Day classification. ${ }^{[13]}$ The larger peak separations $\Delta E_{1 / 2}$ of around $250 \mathrm{mV}$ in the endo com- pounds 15 and 16 are consistent with previous observations that the distance between redox-active centers in conjugated mixed-valence compounds is inversely related to their redox peak separation. ${ }^{[14]}$ The comproportionation constants for 15 and 16 are on the order of $K_{\mathrm{C}}=4 \times 10^{4}$, which is indicative of weakly coupled Class II systems. ${ }^{[12]}$

The nature of the substituents has a much larger role in determining the reduction potentials than the oxidation potentials, indicating that reduction is likely centered on the dicarboxylic substituents. The first reduction is easier in $\mathbf{1 5}$ and 16, in which the substituents are closer to the center of the conjugated system, as compared with 11 and 12. However, the second reduction is significantly more difficult than the first reduction in $\mathbf{1 5}$ and $\mathbf{1 6}$ because the proximity and electronic coupling of the substituents make it difficult to generate a second charge. In 11 and 12, $\Delta E_{1 / 2}$ is small because the second charge created upon second reduction is located further away from the first charge.

From the first oxidation and reduction potentials, electrochemical band gaps of 2.54 (16), 2.62 (12), 3.04 (15), and $3.07(11) \mathrm{eV}$ are obtained. These values are respectively $0.35,0.26,0.22$, and $0.15 \mathrm{eV}$ higher than the optical band gap values estimated above from the absorption edges. The difference corresponds to the exciton binding energy in the neutral excited molecule, which is typically found to be of the order of $0.3 \mathrm{eV} .^{[15]}$

With $E_{1 / 2}\left(\mathrm{Fc}^{+} / \mathrm{Fc}\right)$ at $4.80 \mathrm{eV}$ below vacuum, the first reduction and oxidation potentials translate into lowest unoccupied molecular orbital energies $E_{\mathrm{LUMO}}$ of -3.45 (16), -3.20 (12), -2.95 (15), and -2.77 (11) eV and highest occupied molecular orbital energies $E_{\mathrm{HOMO}}$ of $-5.98(\mathbf{1 6}),-5.82$ (12), -5.98 (15), and -5.84 (11) eV.

\section{Conclusions}

As an alternative to the condensation of an aryl-monoglyoxylic acid with a dibromoarylene-diacetic acid, the condensation of a bromoaryl-acetic acid with an arylene-diglyoxylic acid is shown to be a viable new path to arenetetracarboxylic esters and imides. To provide access to arylene-diglyoxylic acids, a dibromoarene is reacted with butyllithium at low temperature followed by reaction of the resulting arene-dianion with diethyl oxalate. Analogous implementation of the two complementary approaches leads to isomerically substituted tetracarboxy-derivatives of the same elongated kata-annellated hydrocarbon, dinaphtho[1,2- $\left.a ; 1^{\prime}, 2^{\prime}-h\right]$ anthracene. This allows us to assert that the positioning of electron-withdrawing substituents on aromatic chromophores has a significant influence on their electronic structure, and that the localization of such substituents on central positions of elongated polycyclic arenes can considerably shift the absorption to longer wavelengths and thus reduce the band gap as well as $E_{\text {LuMO. The re- }}$ duction potentials are found to be much more dependent on the nature and the positioning of the carboxylic substituents than the oxidation potentials, implying that oxidation is centered largely on the aromatic core, whereas reduction is largely centered on the substituents. 


\section{Experimental Section}

Diethyl Anthrylene-1,5-diglyoxylate (8): To a stirred suspension of 1,5-dibromoanthracene $7^{[9]}(4.00 \mathrm{~g}, 336.0 \mathrm{~g} / \mathrm{mol}, 11.9 \mathrm{mmol})$ in anhydrous THF $(400 \mathrm{~mL})$ under argon, a solution of butyllithium $(2.5 \mathrm{M}$ in hexane, $19 \mathrm{~mL}, 47.5 \mathrm{mmol})$ was added dropwise at $-94{ }^{\circ} \mathrm{C}$ (acetone-liquid nitrogen cooling bath), and the orange mixture was stirred for $4 \mathrm{~h}$ at $-94{ }^{\circ} \mathrm{C}$. Diethyl oxalate $(15 \mathrm{~mL}, 1.077 \mathrm{~g} / \mathrm{mL}, 16 \mathrm{~g}$, $146.1 \mathrm{~g} / \mathrm{mol}, 110 \mathrm{mmol})$ was quickly added at $-94^{\circ} \mathrm{C}$. After $30 \mathrm{~min}$ at $-94^{\circ} \mathrm{C}$, the cooling bath was removed and stirring was continued for $1 \mathrm{~h}$ at room temperature. $\mathrm{CH}_{2} \mathrm{Cl}_{2}(200 \mathrm{~mL})$ was added, followed by $1 \mathrm{M}$ hydrochloric acid $(100 \mathrm{~mL})$, the phases were separated, the aqueous phase was extracted with $\mathrm{CH}_{2} \mathrm{Cl}_{2}(2 \times 100 \mathrm{~mL})$, and the combined organic phases were dried with sodium sulfate and concentrated. Cold methanol $(750 \mathrm{~mL})$ was added while stirring, and the precipitated product was filtered off and purified by column chromatography on silica $\left(\mathrm{CH}_{2} \mathrm{Cl}_{2}\right)$ and recrystallized from ethanol, yield $3.60 \mathrm{~g}(378.4 \mathrm{~g} / \mathrm{mol}, 9.5 \mathrm{mmol}, 80 \%)$; yellow felt-like solid; m.p. $168-171^{\circ} \mathrm{C} .{ }^{1} \mathrm{H}$ NMR $\left(400 \mathrm{MHz}, \mathrm{CDCl}_{3}\right): \delta=9.84$ (s, 2 $\mathrm{H}), 8.22(\mathrm{dd}, J=8,1 \mathrm{~Hz}, 2 \mathrm{H}), 8.13(\mathrm{dd}, J=7,1 \mathrm{~Hz}, 2 \mathrm{H}), 7.63$ $(\mathrm{dd}, J=8,7 \mathrm{~Hz}, 2 \mathrm{H}), 4.52(\mathrm{q}, J=7 \mathrm{~Hz}, 4 \mathrm{H}), 1.47(\mathrm{t}, J=7 \mathrm{~Hz}$, $6 \mathrm{H}) \mathrm{ppm} .{ }^{13} \mathrm{C} \mathrm{NMR}\left(100 \mathrm{MHz}, \mathrm{CDCl}_{3}\right): \delta=188.8,164.7,138.0$, $136.8,133.9,128.4,128.0,127.2,124.9,62.7,14.4$ ppm. FDHRMS: $m / z$ calcd. for $\mathrm{C}_{22} \mathrm{H}_{18} \mathrm{O}_{6}[\mathrm{M}]^{+} 378.1103$; found 378.1115 .

Anthrylene-1,5-diglyoxylic Acid (6): Diethyl anthrylene-1,5-diglyoxylate $8(3.78 \mathrm{~g}, 378.4 \mathrm{~g} / \mathrm{mol}, 10 \mathrm{mmol})$ was suspended in ethanol $(125 \mathrm{~mL})$. A solution of sodium hydrogen carbonate $(8.4 \mathrm{~g}, 84.0 \mathrm{~g} /$ mol, $100 \mathrm{mmol})$ in water $(250 \mathrm{~mL})$ was added and the mixture was stirred and heated to reflux for $4 \mathrm{~h}$. The resulting homogeneous solution was poured into $5 \%$ aqueous hydrochloric acid $(500 \mathrm{~mL})$. The precipitate was filtered off, washed with $5 \%$ aqueous hydrochloric acid, and allowed dry in air. The yellow solid product ( $3.22 \mathrm{~g}, 322.3 \mathrm{~g} / \mathrm{mol}, 10 \mathrm{mmol}$, quantitative yield) was used without further purification. m.p. $>250{ }^{\circ} \mathrm{C}$ (dec.). ${ }^{1} \mathrm{H} \mathrm{NMR}(400 \mathrm{MHz}$, [D ${ }_{6}$ DMSO): $\delta=9.78(\mathrm{~s}, 2 \mathrm{H}), 8.62$ (d, $\left.J=8.5 \mathrm{~Hz}, 2 \mathrm{H}\right), 8.24$ (d, $J=7 \mathrm{~Hz}, 2 \mathrm{H}$ ), $7.80(\mathrm{t}, J=8 \mathrm{~Hz}, 2 \mathrm{H}$ ) ppm (no discrete acid proton detected). ${ }^{13} \mathrm{C}$ NMR [100 MHz, [D $]$ DMSO]: $\delta=191.0,166.4$, $137.4,136.7,133.1,127.4,127.1,126.2,125.6$ ppm. FD-HRMS: $\mathrm{m} / \mathrm{z}$ calcd. for $\mathrm{C}_{18} \mathrm{H}_{10} \mathrm{O}_{6}[\mathrm{M}]^{+}$322.0477; found 322.04775 .

Tetraethyl 1,5-Anthrylenebis[(2-bromophenyl)maleate] (10): Anthrylene-1,5-diglyoxylic acid 6 (1.61 g, $322.3 \mathrm{~g} / \mathrm{mol}, 5 \mathrm{mmol})$, 2-bromophenylacetic acid $9(2.58 \mathrm{~g}, 215.0 \mathrm{~g} / \mathrm{mol}, 12 \mathrm{mmol})$, triethylamine $(5 \mathrm{~g}, 101.2 \mathrm{~g} / \mathrm{mol}, 0.05 \mathrm{~mol})$, and acetic anhydride $(7 \mathrm{~g}, 102.1 \mathrm{~g} / \mathrm{mol}$, $0.07 \mathrm{~mol})$ were stirred and heated to reflux in anhydrous THF $(60 \mathrm{~mL})$ under argon for $20 \mathrm{~h}$. A solution of DBU $(15 \mathrm{~g}$, $152.2 \mathrm{mmol}, 0.1 \mathrm{~mol})$, ethanol $(20 \mathrm{~g}, 46.1 \mathrm{~g} / \mathrm{mol}, 0.4 \mathrm{~mol})$, and bromoethane $(20 \mathrm{~g}, 109.0 \mathrm{~g} / \mathrm{mol}, 0.2 \mathrm{mmol})$ in anhydrous THF $(50 \mathrm{~mL})$ was then added and the mixture was stirred and heated to reflux under exclusion of moisture for $24 \mathrm{~h}$. Chloroform and 5\% aqueous hydrochloric acid were added, the phases were separated, the aqueous phase was extracted with chloroform, the combined chloroform extracts were dried with sodium sulfate, the solvent was evaporated, and the resulting crude product was purified by column chromatography $\left(\mathrm{CH}_{2} \mathrm{Cl}_{2}\right.$ containing $1 \%$ ethanol) on silica and recrystallized from ethanol, yield $1.33 \mathrm{~g}(828.5 \mathrm{~g} / \mathrm{mol}$, $1.61 \mathrm{mmol}, 32 \%)$; yellow solid; m.p. $210-213{ }^{\circ} \mathrm{C} .{ }^{1} \mathrm{H}$ NMR $\left(400 \mathrm{MHz}, \mathrm{CD}_{2} \mathrm{Cl}_{2}\right): \delta=8.80-8.45($ broad, $2 \mathrm{H}), 7.97(\mathrm{~d}, J=$ $8.5 \mathrm{~Hz}, 2 \mathrm{H}), 7.70-7.15$ (2 broad overlapping peaks, $6 \mathrm{H}), 7.10$ 6.65 (2 broad overlapping peaks, $6 \mathrm{H}), 4.30(\mathrm{q}, J=7 \mathrm{~Hz}, 4 \mathrm{H})$, $4.40-4.10$ (broad, $4 \mathrm{H}$ ), $1.30(\mathrm{t}, J=7 \mathrm{~Hz}, 6 \mathrm{H}$ ), 1.35-1.15 (broad, $6 \mathrm{H}) \mathrm{ppm}$. The strong signal broadening due to slow rotations, evident from the ${ }^{1} \mathrm{H}$ NMR spectrum, did not allow the recording of a meaningful ${ }^{13} \mathrm{C}$ NMR spectrum. FD-HRMS: $\mathrm{m} / \mathrm{z}$ calcd. for $\mathrm{C}_{42} \mathrm{H}_{36} \mathrm{Br}_{2} \mathrm{O}_{8}[\mathrm{M}]^{+}$826.0777; found 826.0777.

Tetraethyl 2,5-Dibromo-1,4-phenylenebis[(1-naphthyl)maleate] (14): Prepared from 2,5-dibromophenylene-1,4-diacetic acid $\mathbf{1}^{[6]}(1.76 \mathrm{~g}$, $352.0 \mathrm{~g} / \mathrm{mol}, 5 \mathrm{mmol})$ and naphthylglyoxylic acid $\mathbf{1 3}^{[10]}(2.40 \mathrm{~g}$, $200.2 \mathrm{~g} / \mathrm{mol}, 12 \mathrm{mmol}$ ) by following the preceding procedure for the preparation of $\mathbf{1 0}$ from $\mathbf{6}$ and $\mathbf{9}$, yield $2.18 \mathrm{~g}(828.5 \mathrm{~g} / \mathrm{mol}$, $2.63 \mathrm{mmol}, 53 \%$ ); off-white solid; m.p. $206-209^{\circ} \mathrm{C} .{ }^{1} \mathrm{H}$ NMR $\left(400 \mathrm{MHz}, \mathrm{CD}_{2} \mathrm{Cl}_{2}\right.$ ): $\delta=8.20-6.40$ (5 broad overlapping peaks, 16 $\mathrm{H}), 4.40-3.90$ (broad, $8 \mathrm{H}$ ), $1.20(\mathrm{t}, J=7 \mathrm{~Hz}, 6 \mathrm{H}), 1.25-0.90$ (broad, $6 \mathrm{H}$ ) ppm. The strong signal broadening due to slow rotations, evident from the ${ }^{1} \mathrm{H}$ NMR spectrum, did not allow the recording of a meaningful ${ }^{13} \mathrm{C} \mathrm{NMR}$ spectrum. FD-HRMS: $\mathrm{m} / \mathrm{z}$ calcd. for $\mathrm{C}_{42} \mathrm{H}_{36} \mathrm{Br}_{2} \mathrm{O}_{8}[\mathrm{M}]^{+}$826.0777; found 826.0779.

Tetraethyl Dinaphtho[1,2-a;1', $\mathbf{2}^{\prime}$ - $h \mid$ anthracene-8,9,17,18-tetracarboxylate (11): Tetraethyl 1,5-anthrylenebis[(2-bromophenyl)maleate] $10(1.66 \mathrm{~g}, 828.5 \mathrm{~g} / \mathrm{mol}, 2 \mathrm{mmol})$, palladium diacetate $(0.09 \mathrm{~g}$, $225.5 \mathrm{~g} / \mathrm{mol}, 0.4 \mathrm{mmol})$, tricyclohexylphosphine $(0.24 \mathrm{~g}, 280.4 \mathrm{~g} /$ $\mathrm{mol}, 0.9 \mathrm{mmol})$, and potassium carbonate $(2.76 \mathrm{~g}, 138.2 \mathrm{~g} / \mathrm{mol}$, $20 \mathrm{mmol}$ ) were stirred at $110^{\circ} \mathrm{C}$ in anhydrous dimethylacetamide (DMA, $30 \mathrm{~mL}$ ) under argon for $16 \mathrm{~h}$. After cooling to room temperature, hot chloroform was added, the solids were filtered off, the filtrate was washed with $5 \%$ aqueous hydrochloric acid, dried with sodium sulfate, and concentrated. The crude product was precipitated by adding ethanol, and the precipitate was filtered off and purified by column chromatography on silica in chloroform and recrystallized from butanol, yield $0.61 \mathrm{~g}(666.7 \mathrm{~g} / \mathrm{mol}, 0.91 \mathrm{mmol}$, $46 \%$ ); pale-yellow solid; m.p. $>300{ }^{\circ} \mathrm{C} .{ }^{1} \mathrm{H}$ NMR $(400 \mathrm{MHz}$, $\left.\mathrm{CDCl}_{3}\right): \delta=8.85(\mathrm{~s}, 2 \mathrm{H}), 8.78(\mathrm{~d}, J=8 \mathrm{~Hz}, 2 \mathrm{H}), 8.67(\mathrm{~d}, J=$ $9 \mathrm{~Hz}, 2 \mathrm{H}), 8.17$ (d, $J=8 \mathrm{~Hz}, 2 \mathrm{H}), 8.12(\mathrm{~d}, J=9 \mathrm{~Hz}, 2 \mathrm{H}), 7.80$ $(\mathrm{t}, J=7.5 \mathrm{~Hz}, 2 \mathrm{H}), 7.70(\mathrm{t}, J=7.5 \mathrm{~Hz}, 2 \mathrm{H}), 4.60(\mathrm{q}, J=7 \mathrm{~Hz}, 4$ $\mathrm{H}), 4.50(\mathrm{q}, J=7 \mathrm{~Hz}, 4 \mathrm{H}), 1.50(\mathrm{t}, J=7 \mathrm{~Hz}, 4 \mathrm{H}), 1.27(\mathrm{t}, J=$ $7 \mathrm{~Hz}, 4 \mathrm{H}) \mathrm{ppm} .{ }^{13} \mathrm{C} \mathrm{NMR}\left(100 \mathrm{MHz}, \mathrm{CDCl}_{3}\right): \delta=171.0,168.6$, $131.4,130.71,130.68,130.6,130.2,128.7,128.4,128.3,128.1$, $127.8,126.3$ (×2), 123.9, 123.8, 121.5, 62.6, 62.5, 14.4, $14.1 \mathrm{ppm}$. FD-HRMS: $m / z$ calcd. for $\mathrm{C}_{42} \mathrm{H}_{34} \mathrm{O}_{8}[\mathrm{M}]^{+}$666.2254; found 666.2251 .

Tetraethyl Dinaphtho[1,2-a; $1^{\prime}, 2^{\prime}$ - $\left.h\right]$ anthracene-5,6,14,15-tetracarboxylate (15): Prepared from $\mathbf{1 4}$ by following the procedure for the preparation of 11 from 10 , yield $0.92 \mathrm{~g}(666.7 \mathrm{~g} / \mathrm{mol}, 1.38 \mathrm{mmol}$, $69 \%$ ); pale-yellow felt-like solid; m.p. $269-272{ }^{\circ} \mathrm{C} .{ }^{1} \mathrm{H}$ NMR (400 MHz, $\mathrm{CD}_{2} \mathrm{Cl}_{2}$ ): $\delta=9.65$ (s, $\left.2 \mathrm{H}\right), 8.87(\mathrm{~d}, J=9 \mathrm{~Hz}, 2 \mathrm{H}), 8.33$ $(\mathrm{d}, J=7.5 \mathrm{~Hz}, 2 \mathrm{H}), 8.24(\mathrm{~d}, J=9 \mathrm{~Hz}, 2 \mathrm{H}), 8.09(\mathrm{~d}, J=7.5 \mathrm{~Hz}$, $2 \mathrm{H}), 7.70(\mathrm{t}, J=7.5 \mathrm{~Hz}, 2 \mathrm{H}), 7.66(\mathrm{t}, J=7.5 \mathrm{~Hz}, 2 \mathrm{H}), 4.68(\mathrm{q}$, $J=7 \mathrm{~Hz}, 4 \mathrm{H}), 4.50(\mathrm{q}, J=7 \mathrm{~Hz}, 4 \mathrm{H}), 1.55(\mathrm{t}, J=7 \mathrm{~Hz}, 4 \mathrm{H})$, $1.35(\mathrm{t}, J=7 \mathrm{~Hz}, 4 \mathrm{H}) \mathrm{ppm} .{ }^{13} \mathrm{C} \mathrm{NMR}\left(100 \mathrm{MHz}, \mathrm{CDCl}_{3}\right): \delta=$ $170.6,168.5,133.4,131.4,130.6,130.5,130.1,129.8,129.6,128.9$, $127.1,126.8,126.6,126.4,124.4,121.5,120.9,62.7,62.6,14.5$, 14.0 ppm. FD-HRMS: $\mathrm{m} / \mathrm{z}$ calcd. for $\mathrm{C}_{42} \mathrm{H}_{34} \mathrm{O}_{8}[\mathrm{M}]^{+}$666.2254; found 666.2256 .

$N, N^{\prime}$-Bis(1-pentylhexyl) Dinaphtho[1,2-a;1', $\left.2^{\prime}-h\right]$ anthracene8,9:17,18-tetracarboxdiimide (12): Tetraethyl dinaphtho[1,2- $a ; 1^{\prime}, 2^{\prime}$ h] anthracene-8,9,17,18-tetracarboxylate $11(0.20 \mathrm{~g}, 666.7 \mathrm{~g} / \mathrm{mol}$, $0.30 \mathrm{mmol}), 6$-aminoundecane ${ }^{[16]}(0.34 \mathrm{~g}, 171.3 \mathrm{~g} / \mathrm{mol}, 2 \mathrm{mmol})$, and imidazole $(5 \mathrm{~g})$ were stirred and heated to reflux in $o$-dichlorobenzene $(10 \mathrm{~g})$ under argon for $6 \mathrm{~h}$. After cooling to room temperature, the solidified mixture was dissolved in hot chloroform, the solution was washed with $5 \%$ aqueous hydrochloric acid, and the chloroform was evaporated. The product was precipitated by adding methanol and purified by column chromatography (chloroform) on silica and recrystallized from xylenes, yield $0.185 \mathrm{~g}$ $(825.1 \mathrm{~g} / \mathrm{mol}, 0.30 \mathrm{mmol}, 75 \%)$; orange solid; m.p. $>300{ }^{\circ} \mathrm{C} .{ }^{1} \mathrm{H}$ 
NMR (400 MHz, $\mathrm{CD}_{2} \mathrm{Cl}_{2}$ ): $\delta=10.28(\mathrm{~s}, 2 \mathrm{H}), 9.41(\mathrm{~d}, J=8 \mathrm{~Hz}, 2$ $\mathrm{H}), 8.88(\mathrm{~d}, J=8 \mathrm{~Hz}, 2 \mathrm{H}), 8.82(\mathrm{~d}, J=9.5 \mathrm{~Hz}, 2 \mathrm{H}), 8.45(\mathrm{~d}, J=$ $9.5 \mathrm{~Hz}, 2 \mathrm{H}), 7.92(\mathrm{t}, J=7.5 \mathrm{~Hz}, 2 \mathrm{H}), 7.86(\mathrm{t}, J=7.5 \mathrm{~Hz}, 2 \mathrm{H})$, $4.43(\mathrm{tt}, J=10,5 \mathrm{~Hz}, 2 \mathrm{H}), 2.32-2.20(\mathrm{~m}, 4 \mathrm{H}), 1.90-1.79(\mathrm{~m}, 4$ $\mathrm{H}), 1.48-1.25(\mathrm{~m}, 24 \mathrm{H}), 0.87(\mathrm{t}, J=7 \mathrm{~Hz}, 12 \mathrm{H}) \mathrm{ppm} .{ }^{13} \mathrm{C} \mathrm{NMR}$ $\left(100 \mathrm{MHz}, \mathrm{CDCl}_{3}\right): \delta=170.03,169.97,134.2,133.3,132.4,130.6$, $129.8,129.5,128.8,127.9,127.8,127.3,126.5,126.2,124.8,123.8$, 121.1, 52.7, 32.7, 31.8, 26.8, 22.9, 14.3 ppm. FD-HRMS: $\mathrm{m} / z$ calcd. for $\mathrm{C}_{56} \mathrm{H}_{60} \mathrm{~N}_{2} \mathrm{O}_{4}[\mathrm{M}]^{+}$824.4553; found 824.4558.

\section{$N, N^{\prime}$-Bis(1-pentylhexyl)}

Dinaphtho[1,2-a; $\left.1^{\prime}, 2^{\prime}-h\right]$ anthracene5,6:14,15-tetracarboxdiimide (16): Prepared from 15 by following the procedure used for the preparation of $\mathbf{1 2}$ from $\mathbf{1 1}$, yield $0.21 \mathrm{~g}$ (825.1 g/mol, $0.30 \mathrm{mmol}, 85 \%)$; red solid; m.p. $>300{ }^{\circ} \mathrm{C} .{ }^{1} \mathrm{H}$ NMR $\left(400 \mathrm{MHz}, \mathrm{CDCl}_{3}\right): \delta=10.90(\mathrm{~s}, 2 \mathrm{H}), 9.49(\mathrm{~d}, J=8 \mathrm{~Hz}, 2 \mathrm{H}), 9.09$ $(\mathrm{d}, J=9 \mathrm{~Hz}, 2 \mathrm{H}), 8.26(\mathrm{~d}, J=9 \mathrm{~Hz}, 2 \mathrm{H}), 8.04(\mathrm{~d}, J=7.5 \mathrm{~Hz}, 2$ $\mathrm{H}), 7.77(\mathrm{t}, J=7.5 \mathrm{~Hz}, 2 \mathrm{H}), 7.72(\mathrm{t}, J=7 \mathrm{~Hz}, 2 \mathrm{H}), 4.44(\mathrm{tt}, J=$ $9.5,5 \mathrm{~Hz}, 2 \mathrm{H}), 2.33-2.21(\mathrm{~m}, 4 \mathrm{H}), 1.93-1.82(\mathrm{~m}, 4 \mathrm{H}), 1.46-1.23$ $(\mathrm{m}, 24 \mathrm{H}), 0.86(\mathrm{t}, J=7 \mathrm{~Hz}, 12 \mathrm{H}) \mathrm{ppm} .{ }^{13} \mathrm{C} \mathrm{NMR}(100 \mathrm{MHz}$, $\left.\mathrm{CDCl}_{3}, 55^{\circ} \mathrm{C}\right): \delta=170.5,169.9,134.5,133.9,132.6,132.0,130.7$, 130.3, 129.6, 129.0, 128.2, 128.1, 126.8, 125.9, 124.8, 122.3, 122.0, 53.3, 33.0, 31.9, 26.9, 22.8, $14.2 \mathrm{ppm}$. FD-HRMS: $\mathrm{m} / \mathrm{z}$ calcd. for $\mathrm{C}_{56} \mathrm{H}_{60} \mathrm{~N}_{2} \mathrm{O}_{4}[\mathrm{M}]^{+}$824.4553; found 824.4556.

Supporting Information (see footnote on the first page of this article): Electrochemical data, ${ }^{1} \mathrm{H}$ and ${ }^{13} \mathrm{C}$ NMR spectra.

\section{Acknowledgments}

This research was financed partially by Agence Nationale de la Recherche (ANR) (project 13-JS07-0009-01) and Coordenação de Aperfeiçoamento de Pessoal de Nível Superior-Comité Français d'Evaluation de la Coopération Universitaire et Scientifique avec le Brésil (CAPES-COFECUB) (project $\mathrm{Ph}-\mathrm{C}$ 803-14) grants.
[1] a) W. Herbst, K. Hunger, Industrial Organic Pigments, 2nd edition, Wiley-VCH, Weinheim, Germany, 1997; b) K.-Y. Law, Chem. Rev. 1993, 93, 449; c) C. Huang, S. Barlow, S. R. Marder, J. Org. Chem. 2011, 76, 2386; d) N. G. Pschirer, C. Kohl, F. Nolde, J. Qu, K. Müllen, Angew. Chem. Int. Ed. 2006, 45, 1401; Angew. Chem. 2006, 118, 1429.

[2] Z. Yuan, Y. Xiao, X. Qian, Chem. Commun. 2010, 46, 2772.

[3] a) S. Iijima, T. Ichihashi, Nature 1993, 363, 603; b) M. Monthioux, V. L. Kuznetsov, Carbon 2006, 44, 1621.

[4] K. S. Novoselov, A. K. Geim, S. V. Morozov, D. Jiang, Y. Zhang, S. V. Dubonos, I. V. Grigorieva, A. A. Firsov, Science 2004, 306, 666.

[5] Y.-W. Son, M. L. Cohen, S. G. Louie, Phys. Rev. Lett. 2006, 97, 216803.

[6] P. Sarkar, F. Durola, H. Bock, Chem. Commun. 2013, 49, 7552. Note that in the Supporting Information file of this paper the reaction temperature for palladium couplings in DMA should read " $110^{\circ} \mathrm{C}$ ", not "reflux".

[7] C. F. Koelsch, S. Wawzonek, J. Org. Chem. 1941, 6, 684.

[8] L. Nassar-Hardy, C. Deraedt, E. Fouquet, F.-X. Felpin, Eur. J. Org. Chem. 2011, 4616.

[9] A. Lohr, T. W. Swager, J. Mater. Chem. 2010, 20, 8107.

[10] F. F. Blicke, R. F. Feldkamp, J. Am. Chem. Soc. 1944, 66, 1087.

[11] H. Bock, S. Huet, P. Dechambenoit, E. A. Hillard, F. Durola, Eur. J. Org. Chem. DOI: 10.1002/ejoc.201403341, following article.

[12] D. E. Richardson, H. Taube, Inorg. Chem. 1981, 20, 1278.

[13] M. B. Robin, P. Day, Adv. Inorg. Chem. Radiochem. 1968, 10, 247.

[14] W. Kaim, A. Klein, M. Glöckle, Acc. Chem. Res. 2000, 33, 755, and references cited therein.

[15] a) M. Knupfer, Appl. Phys. A 2003, 77, 623; b) D. R. T. Zahn, T. U. Kampen, H. Méndez, Appl. Surf. Sci. 2003, 212-213, 423; c) H. Bock, D. Subervie, P. Mathey, A. Pradhan, P. Sarkar, P. Dechambenoit, E. A. Hillard, F. Durola, Org. Lett. 2014, 16, 1546, and page 2573 (Erratum).

[16] S. J. Manning, W. Bogen, L. A. Kelly, J. Org. Chem. 2011, 76, 6007. 